\title{
Exploring the Corporate Dividend Payment Behavior of the Japanese Chemicals Industry Firms
}

\author{
Chikashi Tsuji*
}

Graduate School of Systems and Information Engineering, University of Tsukuba, Japan

\begin{abstract}
This article explores the corporate dividend payment behavior of the Japanese chemicals industry firms. According to our empirical examinations, the Japanese chemicals industry firms do not cater to investors' dividend demands when they decide both their dividend initiations and continuations. Instead of catering factor, in this industry, our empirical examinations reveal that the determinants of corporate dividend policies are value-weighted size, valueweighted dividend yields, and value-weighted nonpayers' or payers' market-to-book ratio. In addition, although our crosssectional tests generally imply the relations between corporate dividend payments and firm earnings, on an aggregate time-series basis, dividend initiations tend to decline corporate earnings in the following year in this Japanese industry. This evidence can be interpreted as the denial of the traditional signaling hypothesis of dividend policy in the Japanese chemicals industry firms.
\end{abstract}

Keywords: Catering theory of dividends, dividend policy, imperfect market, inefficient market, signaling hypothesis.

\section{INTRODUCTION}

Assuming the perfect and efficient capital markets, Miller and Modigliani (MM) [1] proved that dividend policy is irrelevant to firm value. After this suggestion was published, numerous researchers criticized this proposition from different viewpoints. ${ }^{1}$

Recently, a new theory, which is called the "catering theory of dividends" was exhibited by Baker and Wurgler (BW) [2]. Relaxing the assumption of perfect markets and efficient markets ${ }^{2}$ in MM [1], and considering psychological phenomena and institutional restrictions, BW [2] insisted as follows by constructing a simple theoretical model. First, some market participants have an uninformed and timevarying demand for dividend-paying shares. Next, arbitrage fails to prevent this demand from driving apart the prices of dividend payers and nonpayers. Finally, corporate managers rationally cater to investor demand. Namely, managers pay dividends when payers are highly valued in the markets, and they do not pay when market participants prefer nonpayers.

*Address correspondence to this author at the Graduate School of Systems and Information Engineering, University of Tsukuba, 1-1-1 Tennodai, Tsukuba, Ibaraki 305-8573 Japan; Tel: +81-29-853-2111;

E-mail: mail_sec_low@minos.ocn.ne.jp

${ }^{1}$ Important studies that follow MM [1] are Allen et al. [3], Asquith and Mullins [4], Bagwell and Shoven [5], Baker and Wurgler [2, 6], Benartzi et al. [7], Black [8], Black and Scholes [9], Dann [10], DeAngelo et al. [11], Eades et al. [12], Fama and French [13], Graham and Harvey [14], Hakansson [15], Healy and Palepu [16], John and Williams [17], Kothari and Shanken [18], La Porta et al. [19], Lintner [20], Long [21], Marsh and Merton [22], Michaely et al. [23], Miller [24], Miller and Rock [25], Miller and Scholes [26], Peterson et al. [27], Poterba [28], Shefrin and Statman [29], and Watts [30], for instance.

${ }^{2}$ Evidence of inefficient markets was recently presented in studies such as Shleifer [31] and Stein [32,33].
As far as we know, this interesting theory has not been examined in Japan except for Tsuji [34]; thus, testing catering theory by exploiting the Japanese specific industry data is an objective of this paper. ${ }^{3}$ More precisely, we investigate the catering theory of dividends in the Japanese chemicals industry, which is one of the most important industries in Japan. Moreover, extending BW's [2] analysis, we further explore the determinants of the dividend payments of the Japanese chemicals industry firms from both cross-sectional and aggregate time-series viewpoints.

The results obtained in this article are first, regarding dividend initiations and continuations for the Japanese chemicals industry firms, the dividend premium is not a determinant. This means that these corporations in Japan do not behave as indicated by catering theory.

Second, contrary to the US case, value-weighted dividend yields, value-weighted size, and value-weighted nonpayers' market-to-book ratio are the determinants of oneyear-ahead dividend initiations in the chemicals industry corporations in Japan.

Third, in the cross-sectional basis, we find a relation between firm earnings and corporate dividend decisions; however, from an aggregate time-series viewpoint, in the Japanese chemicals industry, we reveal that corporate earnings tend to decline in the year following dividend initiations. This is important since this evidence is against the signaling hypothesis of dividend policy.

The rest of the article is organized as follows. Section II summarizes BW's [2] catering theory of dividends and our testing methodology, Section III explains the data, Sections

\footnotetext{
${ }^{3}$ There exist several international studies which are based on or related to the catering theory of dividends. Those are such as Korkeamaki et al. [35], Baker [36], Baker et al. [37], Chay and Suh [38], Hoberg and Prabhala [39], Denis and Osobov [40], Blau and Fuller [41], Liu et al. [42], Banerjee et al. [43], and Li and Lie [44], for example.
} 
IV to VI demonstrate the empirical results, and Section VII concludes the article.

\section{THEORY AND METHODOLOGY}

We first test the catering theory, and then extend the research of BW [2]. The catering theory of dividends of BW [2] insisted that real financial markets are inefficient and imperfect, and firms make their dividend initiation and continuation decisions by catering for the investors' dividend demands. According to BW [2], the market participants' dividend demands can be captured by the difference between payers' M/Bs and nonpayers' M/Bs. Also BW [2] suggested that corporate managers can observe the difference through real equity markets. Therefore, catering theory predicts that when the payers' $\mathrm{M} / \mathrm{Bs}$ are higher than the nonpayers' $\mathrm{M} / \mathrm{Bs}$, corporate managers initiate or continue dividend payments by catering for the investors' demands for dividends.

After the examination of catering theory, we next extend BW's [2] investigations. More concretely, the determinants of dividend initiations and continuations in the chemicals industry firms in Japan are explored by applying both crosssectional and aggregate time-series analysis.

\section{DATA CONSTRUCTIONS}

Our dividend payment measures follow BW [2]. All data are from QUICK Corp. The full sample period in this study is from 1986 to 2006. In addition, this research focuses on the corporations in the Japanese chemicals industry.

We focus the Japanese chemicals industry firms because the second largest number of firms of this industry is included in the NIKKEI 500 Index as at the end of December 2009. Hence this industry is one of the largest industries in Japan, and the industry represents the Japanese stock markets. Therefore, we consider that the dividend policies of the companies in this industry are very important and valuable to examine.

Following BW [2], we count a firm as a payer if it has positive dividends per share by the ex date; otherwise, it is a nonpayer. To construct useful time series data by using this firm-level data, we made two aggregate identities in accordance with BW [2]:

$$
\begin{aligned}
& \text { Payers }_{t}=\text { New Payers }{ }_{t}+\text { Old Payers }_{t}+\text { List Payers } \text { L }_{\text {, }}
\end{aligned}
$$

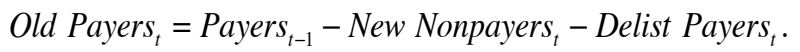

The first variable describes the number of payers, and the second defines the evolution of the payers. Payers denotes the total number of payers, New Payers means the number of initiators among last year's nonpayers, Old Payers denotes the number of payers that also paid last year, List Payers defines the number of payers this year that were not in the sample last year, New Nonpayers denotes the number of omitters among last year's payers, and Delist Payers expresses the number of last year's payers not in the sample this year. In this study, lists and delists are related to the Tokyo Stock Exchange (TSE) First Section.

Then three variables are defined to capture dividend payment dynamics as in BW [2]:

$$
\begin{aligned}
& \text { Initiate }_{t}=\frac{\text { New Payers }_{t}}{\text { Nonpayer }_{t-1}-\text { Delist Nonpayers }_{t}}, \\
& \text { Continue }_{t}=\frac{\text { Old Payers }_{t}}{\text { Payers }_{t-1}-\text { Delist Payers }_{t}}, \\
& \text { Listpay }_{t}=\frac{\text { List Payer }_{t}}{\text { List Payers }_{t}+\text { List Nonpayers }_{t}} .
\end{aligned}
$$

In words, as in BW [2], the rate of initiation (Initiate) is the fraction of surviving nonpayers that become new payers. The rate at which firms continue paying (Continue) is the fraction of surviving payers that continue paying. The rate at which new lists in the sample pay (Listpay) is payers as a percentage of new lists at time $t$. These variables express the decision whether to pay dividends, not how much to pay.

Table 1 shows the aggregate totals and the dividend payment variables for the companies in the Japanese chemicals industry. The initiation rate ups around 1990, and then drops. After that, it rebounds in the middle and late 1990s, declines again in 1999 and 2002, and increases again around the end of the sample period. As expected, the rate at which firms continue paying changes less. Note that the rate at which lists pay is always high, contrary to the case of BW [2], where Listpay varies significantly.

Next are the dividend premium variables in stock markets. It is conceptually important to measure the difference between the market values of firms that have the same investment policy and different dividend policies, since this price difference should be zero in the frictionless and efficient markets assumed in MM [1]. However, with limits to arbitrage, BW [2] insisted that the uninformed demand for dividend-paying stocks causes a price difference, which may vary over time.

Following BW [2], we construct the dividend premium variable, which is expressed as $P^{D-N D}$. This variable is the difference in the logs of the average market-to-book ratios of payers and nonpayers. Market-to-book ratios are defined by following Fama and French (FF) [45, 46]. Namely, the market-to-book ratio is book assets minus book equity plus market equity all divided by book assets.

More precisely, we take equal- and (book) valueweighted averages of the market-to-book ratios separately for payers and nonpayers in each year. Then the final dividend premium series are computed as the difference of the logs of these averages. These series are shown in Table 2.

Moreover, other variables for the additional tests are constructed in Section V and VI. The details of the data constructions are described in Section V and VI.

\section{EMPIRICAL TESTS}

We first test whether catering theory holds in the Japanese chemicals industry. That is, we first examine the relation between dividend payments and the equity market measures of dividend demand. To investigate this relationship formally, Table $\mathbf{3}$ regresses dividend payment measures on the lagged demand for dividends measures: 
Table 1. Dividend Payment Measures

\begin{tabular}{|c|c|c|c|c|c|c|c|c|c|c|c|}
\hline \multirow{2}{*}{ Year } & \multicolumn{4}{|c|}{ Payers } & \multicolumn{4}{|c|}{ Nonpayers } & \multicolumn{3}{|c|}{ Payment Rates (\%) } \\
\hline & Total & New & Old & List & Total & New & Old & List & Initiate & Continue & Listpay \\
\hline 1987 & 75 & 4 & 68 & 3 & 12 & 1 & 11 & 0 & 26.67 & 98.55 & 100.00 \\
\hline 1988 & 79 & 1 & 74 & 4 & 12 & 1 & 11 & 0 & 8.33 & 98.67 & 100.00 \\
\hline 1989 & 86 & 6 & 79 & 1 & 6 & 0 & 6 & 0 & 50.00 & 100.00 & 100.00 \\
\hline 1990 & 89 & 3 & 86 & 0 & 3 & 3 & 0 & 0 & 50.00 & 100.00 & - \\
\hline 1991 & 92 & 1 & 88 & 3 & 3 & 1 & 2 & 0 & 33.33 & 98.88 & 100.00 \\
\hline 1992 & 92 & 0 & 90 & 2 & 5 & 2 & 3 & 0 & 0.00 & 98.83 & 100.00 \\
\hline 1993 & 86 & 0 & 86 & 0 & 11 & 6 & 5 & 0 & 0.00 & 93.48 & - \\
\hline 1994 & 86 & 1 & 78 & 7 & 16 & 6 & 10 & 0 & 9.09 & 92.86 & 100.00 \\
\hline 1995 & 86 & 2 & 83 & 1 & 14 & 0 & 14 & 0 & 12.50 & 100.00 & 100.00 \\
\hline 1996 & 90 & 5 & 84 & 1 & 11 & 2 & 9 & 0 & 35.71 & 97.67 & 100.00 \\
\hline 1997 & 91 & 1 & 90 & 0 & 10 & 0 & 10 & 0 & 9.09 & 100.00 & - \\
\hline 1998 & 94 & 3 & 88 & 3 & 9 & 2 & 7 & 0 & 30.00 & 97.78 & 100.00 \\
\hline 1999 & 89 & 0 & 89 & 0 & 13 & 4 & 9 & 0 & 0.00 & 95.70 & - \\
\hline 2000 & 92 & 4 & 85 & 3 & 12 & 3 & 9 & 0 & 30.77 & 96.59 & 100.00 \\
\hline 2001 & 102 & 3 & 91 & 8 & 11 & 1 & 9 & 1 & 25.00 & 98.91 & 88.89 \\
\hline 2002 & 96 & 0 & 95 & 1 & 17 & 6 & 11 & 0 & 0.00 & 94.06 & 100.00 \\
\hline 2003 & 107 & 7 & 95 & 5 & 10 & 0 & 10 & 0 & 41.18 & 100.00 & 100.00 \\
\hline 2004 & 108 & 2 & 105 & 1 & 8 & 1 & 7 & 0 & 22.22 & 99.06 & 100.00 \\
\hline 2005 & 111 & 2 & 105 & 4 & 7 & 1 & 6 & 0 & 25.00 & 99.06 & 100.00 \\
\hline 2006 & 113 & 1 & 108 & 4 & 7 & 2 & 5 & 0 & 16.67 & 98.18 & 100.00 \\
\hline
\end{tabular}

Notes: A firm is defined as a dividend payer at time $t$ if it has positive dividends per share by the ex date. A firm is defined as a new dividend payer at time $t$ if it has positive dividends per share by the ex date at time $t$ and zero dividends per share by the ex date at time $t-1$. A firm is defined as an old payer at time $t$ if it has positive dividends per share by the ex date at time $t$ and positive dividends per share by the ex date at time $t-1$. A firm is defined as a new list payer if it has positive dividends per share by the ex date at time $t$ and is not in the sample at time $t-1$. A firm is defined as a nonpayer at time $t$ if it does not have positive dividends per share by the ex date. New nonpayers are firms who were payers at time $t-1$ but not at $t$. Old nonpayers are firms who were nonpayers in both $t-1$ and $t$. New list nonpayers are nonpayers at $t$ who were not in the sample at $t-1$. The initiation rate Initiate expresses payers as a percentage of surviving nonpayers from $t-1$. The rate at which firms continue paying dividends Continue expresses payers as a percentage of surviving payers from $t-1$. The rate at which lists pay Listpay expresses payers as a percentage of new lists at $t$.

Table 2. Market Values and the Dividend Premium Measures

\begin{tabular}{|c|c|c|c|c|c|c|}
\hline \multirow{2}{*}{ Year } & \multicolumn{2}{|c|}{ Payers } & \multicolumn{2}{|c|}{ Nonpayers } & \multicolumn{2}{|c|}{ Dividend Premium $\left(P^{D-N D}\right)$} \\
\hline & EWM/B & VWM/B & EWM/B & VWM/B & EW & VW \\
\hline 1986 & 1.72 & 1.56 & 1.55 & 1.35 & 10.11 & 13.97 \\
\hline 1987 & 1.82 & 1.85 & 1.69 & 1.50 & 7.84 & 20.91 \\
\hline 1988 & 2.05 & 2.12 & 1.92 & 1.65 & 6.56 & 25.15 \\
\hline 1989 & 2.21 & 2.26 & 2.22 & 1.97 & -0.50 & 13.64 \\
\hline 1990 & 2.13 & 1.95 & 2.38 & 2.38 & -11.16 & -19.78 \\
\hline 1991 & 1.72 & 1.63 & 1.81 & 1.71 & -5.05 & -4.84 \\
\hline 1992 & 1.45 & 1.43 & 1.43 & 1.29 & 1.60 & 10.69 \\
\hline 1993 & 1.35 & 1.35 & 1.32 & 1.23 & 2.13 & 9.50 \\
\hline 1994 & 1.44 & 1.43 & 1.35 & 1.26 & 6.50 & 12.62 \\
\hline 1995 & 1.32 & 1.34 & 1.27 & 1.28 & 3.66 & 4.57 \\
\hline 1996 & 1.46 & 1.50 & 1.39 & 1.35 & 4.84 & 10.97 \\
\hline 1997 & 1.28 & 1.37 & 1.20 & 1.22 & 5.74 & 11.55 \\
\hline 1998 & 1.11 & 1.26 & 1.05 & 1.04 & 5.64 & 19.05 \\
\hline 1999 & 1.10 & 1.34 & 1.00 & 1.00 & 9.60 & 29.25 \\
\hline 2000 & 1.20 & 1.49 & 0.94 & 0.98 & 24.47 & 41.90 \\
\hline 2001 & 1.17 & 1.38 & 1.10 & 1.21 & 5.55 & 13.00 \\
\hline 2002 & 1.14 & 1.39 & 1.02 & 1.16 & 11.96 & 17.85 \\
\hline 2003 & 1.09 & 1.24 & 1.04 & 1.19 & 5.45 & 4.20 \\
\hline 2004 & 1.27 & 1.44 & 1.26 & 1.52 & 1.06 & -5.59 \\
\hline 2005 & 1.37 & 1.43 & 1.28 & 1.35 & 6.62 & 6.00 \\
\hline 2006 & 1.66 & 1.79 & 1.27 & 1.22 & 26.82 & 38.10 \\
\hline
\end{tabular}

Notes: A firm is defined as a dividend payer at time $t$ if it has positive dividends per share by the ex date. The market-to-book ratio is the ratio of the market value of the firm to its book value. The market-to-book ratio reported is an equal-weighed (EW) or value-weighted (VW) average, by book value across dividend payers and nonpayers. These ratios are calculated for the entire sample and for new lists. A firm is defined as a new list if it is not in the sample at time $t-1$. The dividend premium $P^{D-N D}$ is the difference between the logs of the dividend payers' and nonpayers' average market-to-book ratios. 


$$
\begin{aligned}
& \text { Initiate }_{t}=\mu+\xi P_{t-1}^{D-N D}+\eta_{t}, \\
& \text { Continue }_{t}=\mu+\xi P_{t-1}^{D-N D}+\eta_{t},
\end{aligned}
$$

where Initiate is the rate of initiation, Continue is the rate of continuation, and $P^{D-N D}$ is the value-weighted or equally weighted dividend premium. In the tables, all independent variables are standardized to have unit variance. In addition, because we use the procedure of Newey and West [47], all standard errors are robust to heteroskedasticity and serial correlation.

Table 3. Basic Relationships Between Dividend Payments and Dividend Demands

\begin{tabular}{|l|c|c|c|c|}
\hline & \multicolumn{2}{|c|}{ Panel A: Initiate $_{\boldsymbol{t}}$} & \multicolumn{2}{c|}{ Panel B: Continue $_{\boldsymbol{t}}$} \\
\hline \hline $\mathrm{VW} P^{D-N D}{ }_{t-1}$ & 1.81 & & -0.01 & \\
& {$[0.31]$} & & {$[0.97]$} & \\
$\mathrm{EW} P^{D-N D}{ }_{t-1}$ & & 1.68 & & 0.32 \\
& & {$[0.62]$} & & {$[0.47]$} \\
$N$ & 20 & 20 & 20 & 20 \\
Adj. $R^{2}$ & -0.04 & -0.05 & -0.06 & -0.04 \\
\hline
\end{tabular}

Notes: Regressions of dividend initiation and continuation rates on measures of the dividend premium. For example, the initiation rate is modeled in Panel A as: Initiate $_{t}=\mu+\xi P^{D-N D}{ }_{t-1}+\eta_{t}$.

The initiation rate Initiate expresses payers as a percentage of surviving nonpayers from $t-1$. The continuation rate Continue expresses payers as a percentage of surviving payers from $t-1$. The dividend premium $P^{D-N D}$ is the difference between the logs of the equal-weighted $(\mathrm{EW})$ and value-weighted $(\mathrm{VW})$ market-to-book ratios for dividend payers and nonpayers. The independent variables are standardized to have unit variance. $p$-values in [] are robust to heteroskedasticity and serial correlation by using the method of Newey and West [47]. $N$ is the number of sample and $A d j . R^{2}$ is the adjusted $R$-squared value.

Panel A of Table 3 indicates that neither an increase in the value-weighted market dividend premium nor an increase in the equally weighted market dividend premium is related with an increase in the dividend initiation rate in the next year. Similarly, neither an increase in the value-weighted market dividend premium nor an increase in the equally weighted market dividend premium is related with an increase in the dividend continuation rate in the next year. To sum up, in contrast to the US case in BW [2], as far as we judge by the results of dividend premium measure, the dividend policies of the corporations in the Japanese chemicals industry do not cater for investors' demands for dividends.

\section{ADDITIONAL CROSS-SECTIONAL TESTS}

This section additionally examines the determinants of the dividend payment cross-sectional basis. For the tests, we first apply BW [2] and FF [19]-type logit models. Namely, our first cross-sectional contemporaneous logit models in this study are as follows:

$$
\begin{aligned}
y_{i, t}=\alpha & +\vartheta_{1} T_{S E P_{i, t}} \\
& +\vartheta_{2}\left(\frac{M}{B}\right)_{i, t}+\vartheta_{3}\left(\frac{d A}{A}\right)_{i, t}+\vartheta_{4}\left(\frac{E}{A}\right)_{i, t}+\tau_{i, t},
\end{aligned}
$$

where $y_{i, t}=1$ if the company is a payer and zero otherwise. Furthermore, TSEP means TSE First Section market capitalization percentile (that is, the percentage of firms on the TSE First Section having smaller capitalization than firm $i$ in that year), $M / B$ is the market-to-book ratio, $d A / A$ denotes the total asset growth ratio, and $E / A$ means the after-tax earnings-to-total-asset ratio.

To test the one-year intertemporal relationships further, the following intertemporal models are also estimated:

$$
\begin{aligned}
y_{i, t}=\alpha+ & \vartheta_{1} T S E P_{i, t-1} \\
& +\vartheta_{2}\left(\frac{M}{B}\right)_{i, t-1}+\vartheta_{3}\left(\frac{d A}{A}\right)_{i, t-1}+\vartheta_{4}\left(\frac{E}{A}\right)_{i, t-1}+\tau_{i, t-1} \\
y_{i, t}=\alpha+ & \vartheta_{1} T S E P_{i, t+1}+\vartheta_{2}\left(\frac{M}{B}\right)_{i, t+1} \\
& +\vartheta_{3}\left(\frac{d A}{A}\right)_{i, t+1}+\vartheta_{4}\left(\frac{E}{A}\right)_{i, t+1}+\tau_{i, t+1}
\end{aligned}
$$

where again $y_{i, t}=1$ if the company is a payer and zero otherwise.

Tables 4-6 present the results. Table 4 indicates the results of logit models such as (9), and it shows that the after-tax earnings-to-total-asset ratio is statistically significant and positive excluding the period after the Japanese 1989 stock market crash. Therefore, payers' earnings are high in the year prior to paying dividends.

Next, Table 5 shows the results of logit models such as (8). The table indicates that the after-tax earnings-to-totalasset ratio is statistically significant and strongly positive in general. Hence, Table 5 presents that the relation between earnings and dividend payments are also strong in the year corporations pay dividends.

Finally, Table 6 presents the results of logit models such as (10) and shows that the after-tax earnings-to-total-asset ratio is again statistically significant and positive in general although the significance seems to be lower than in Tables 4 and 5. Therefore, payers' earnings are also high in the year after they pay dividends; however, their financial conditions might be weaker than in the previous two years.

In order to inspect the earnings situations in more detail, we examine the $p$-values of the coefficients of the $E / A \mathrm{~s}$ in models (8) to (10) in Fig. (1). This figure plots the average $p$ values from three kinds of logit models in each year. Smaller $p$-values are more favorable, thus earnings conditions are best in the year they are payers, second best in the year before they pay dividends, and worst in the year after they pay dividends in these three cases. Judging by these results, on a cross-sectional basis, we find that the relation between corporate earnings and dividend payments observed in the Japanese chemicals industry firms weakens in the year after payment of dividends.

Furthermore, the parameters' statistical significances of, in particular, the earnings-to-asset ratios are different from year to year in Tables 4-6. We suggest that the decreases of the parameters' significances of the earnings-to-asset ratios around 1990 are because of the Japanese stock market crash. In addition, we consider that the declines of the parameters' significances of the earnings-to-asset ratios around 1997 are due to the Asian financial crisis effects to the Japanese stock markets and corporations. 
Table 4. Cross-Sectional Determinants of One-Year-Previous Dividend Payments

\begin{tabular}{|c|c|c|c|c|c|c|}
\hline & SIZE $_{t-1}$ & $\mathbf{M} / \mathbf{B}_{t-1}$ & $\mathbf{d} \mathbf{A} / \mathbf{A}_{t-1}$ & $\mathbf{E} / \mathbf{A}_{t-1}$ & $N$ & McFadden R-Squared \\
\hline 1987 & $0.029 * *[0.05]$ & $-0.350[0.725]$ & $0.120[0.102]$ & $\begin{array}{l}1.218^{* * *}[0.009] \\
1.445 * * *[0.004] \\
1.260 * * *[0.007]\end{array}$ & $\begin{array}{l}84 \\
84 \\
84\end{array}$ & $\begin{array}{l}0.369 \\
0.303 \\
0.348\end{array}$ \\
\hline 1988 & $0.033^{* *}[0.028]$ & $-0.057[0.961]$ & $0.009[0.109]$ & $\begin{array}{l}2.127 * * *[0.003] \\
2.030 * * *[0.002] \\
1.774 * * *[0.004]\end{array}$ & $\begin{array}{l}87 \\
87 \\
87\end{array}$ & $\begin{array}{l}0.445 \\
0.360 \\
0.402\end{array}$ \\
\hline 1989 & $0.044 *[0.074]$ & $0.583[0.692]$ & $0.179 *[0.053]$ & $\begin{array}{c}1.808^{* * *}[0.010] \\
2.108^{* * *[0.004]} \\
1.913^{* *}[0.012]\end{array}$ & $\begin{array}{l}91 \\
91 \\
91\end{array}$ & $\begin{array}{l}0.434 \\
0.337 \\
0.483\end{array}$ \\
\hline 1990 & $0.056[0.155]$ & $-3.565^{* *}[0.039]$ & $0.099[0.358]$ & $\begin{array}{c}1.206[0.178] \\
3.060^{* *}[0.026] \\
1.329[0.133]\end{array}$ & $\begin{array}{l}92 \\
92 \\
92\end{array}$ & $\begin{array}{l}0.328 \\
0.386 \\
0.236\end{array}$ \\
\hline 1991 & $0.182 *[0.083]$ & $-0.116[0.876]$ & $0.111[0.142]$ & $\begin{array}{c}-0.048[0.924] \\
0.559[0.408] \\
0.286[0.638]\end{array}$ & $\begin{array}{l}92 \\
92 \\
92\end{array}$ & $\begin{array}{l}0.428 \\
0.032 \\
0.157\end{array}$ \\
\hline 1992 & $0.020[0.329]$ & $-0.487[0.586]$ & $0.0007[0.977]$ & $\begin{array}{l}1.880 * * *[0.006] \\
1.917 * * *[0.005] \\
1.910 * * *[0.005]\end{array}$ & $\begin{array}{l}95 \\
95 \\
95\end{array}$ & $\begin{array}{l}0.384 \\
0.365 \\
0.358\end{array}$ \\
\hline 1993 & $-0.012[0.377]$ & $0.025[0.987]$ & $0.037[0.601]$ & $\begin{array}{l}2.569 * * *[0.001] \\
2.448 * * *[0.001] \\
2.479 * *[0.001]\end{array}$ & $\begin{array}{l}97 \\
97 \\
97\end{array}$ & $\begin{array}{l}0.448 \\
0.436 \\
0.440\end{array}$ \\
\hline 1994 & $0.0007[0.958]$ & $-4.141 * *[0.013]$ & $-0.045[0.473]$ & $\begin{array}{l}1.768^{* * *}[0.000] \\
2.235^{* * *}[0.000] \\
1.768^{* * *}[0.000]\end{array}$ & $\begin{array}{l}95 \\
95 \\
95\end{array}$ & $\begin{array}{l}0.458 \\
0.534 \\
0.464\end{array}$ \\
\hline 1995 & $-0.002[0.897]$ & $-0.301[0.864]$ & $0.042[0.306]$ & $\begin{array}{l}0.907 * * *[0.000] \\
0.914 * * *[0.000] \\
0.865 * *[0.000]\end{array}$ & $\begin{array}{l}99 \\
99 \\
99\end{array}$ & $\begin{array}{l}0.347 \\
0.347 \\
0.359\end{array}$ \\
\hline 1996 & $0.021[0.166]$ & $0.224[0.915]$ & $0.047[0.561]$ & $\begin{array}{l}0.986 * * *[0.001] \\
0.948^{* * *}[0.001] \\
0.912 * *[0.002]\end{array}$ & $\begin{array}{l}102 \\
102 \\
102\end{array}$ & $\begin{array}{l}0.381 \\
0.351 \\
0.357\end{array}$ \\
\hline 1997 & $-0.008[0.625]$ & $-1.453[0.288]$ & $0.103[0.267]$ & $\begin{array}{c}2.089^{* * *}[0.010] \\
2.185^{* * *}[0.009] \\
1.841^{* *}[0.015]\end{array}$ & $\begin{array}{l}101 \\
101 \\
101\end{array}$ & $\begin{array}{l}0.528 \\
0.539 \\
0.543\end{array}$ \\
\hline 1998 & $0.043 * *[0.016]$ & $-0.112[0.946]$ & $0.072[0.263]$ & $\begin{array}{c}0.251 * *[0.031] \\
0.279 *[0.068] \\
0.228 *[0.079]\end{array}$ & $\begin{array}{l}101 \\
101 \\
101\end{array}$ & $\begin{array}{l}0.221 \\
0.090 \\
0.113\end{array}$ \\
\hline 1999 & $0.029 *[0.053]$ & $-1.053[0.561]$ & $0.025[0.639]$ & $\begin{array}{l}1.146^{* * *}[0.004] \\
1.345^{* * *}[0.000] \\
1.300 * *[0.001]\end{array}$ & $\begin{array}{l}102 \\
102 \\
102\end{array}$ & $\begin{array}{l}0.328 \\
0.274 \\
0.275\end{array}$ \\
\hline 2000 & $0.021[0.118]$ & $0.323[0.800]$ & $-0.008[0.321]$ & $\begin{array}{l}0.262^{* * *}[0.005] \\
0.289^{* * *}[0.002] \\
0.366^{* *}[0.003]\end{array}$ & $\begin{array}{l}101 \\
101 \\
101\end{array}$ & $\begin{array}{l}0.231 \\
0.195 \\
0.208\end{array}$ \\
\hline 2001 & $0.037 * *[0.018]$ & $0.603[0.547]$ & $-0.018[0.742]$ & $\begin{array}{l}0.148[0.461] \\
0.072[0.287] \\
0.103[0.190]\end{array}$ & $\begin{array}{l}104 \\
104 \\
104\end{array}$ & $\begin{array}{l}0.136 \\
0.035 \\
0.029\end{array}$ \\
\hline 2002 & $0.007[0.494]$ & $-0.131[0.842]$ & $0.050[0.240]$ & $\begin{array}{c}0.187 * * *[0.010] \\
0.198^{* * *}[0.008] \\
0.187^{* *}[0.013]\end{array}$ & $\begin{array}{l}112 \\
112 \\
112\end{array}$ & $\begin{array}{l}0.096 \\
0.091 \\
0.106\end{array}$ \\
\hline 2003 & $0.029 *[0.051]$ & $-0.209[0.846]$ & $-0.057[0.255]$ & $\begin{array}{l}0.481 * * *[0.001] \\
0.401 * * *[0.000] \\
0.414^{* * *[0.000]}\end{array}$ & $\begin{array}{l}112 \\
112 \\
112\end{array}$ & $\begin{array}{l}0.342 \\
0.275 \\
0.294\end{array}$ \\
\hline 2004 & $0.051 * *[0.018]$ & $-0.526[0.708]$ & $0.180 * *[0.027]$ & $\begin{array}{c}0.574 * * *[0.005] \\
0.465 * *[0.002] \\
0.395^{* *}[0.015]\end{array}$ & $\begin{array}{l}115 \\
115 \\
115\end{array}$ & $\begin{array}{l}0.360 \\
0.216 \\
0.303\end{array}$ \\
\hline 2005 & $0.097 * *[0.042]$ & $-0.626[0.699]$ & $0.024[0.701]$ & $\begin{array}{c}0.381[0.221] \\
0.717 * * *[0.010] \\
0.656^{* *}[0.021]\end{array}$ & $\begin{array}{l}114 \\
114 \\
114\end{array}$ & $\begin{array}{l}0.470 \\
0.268 \\
0.268\end{array}$ \\
\hline 2006 & $0.028[0.137]$ & $-0.904[0.381]$ & $0.075[0.411]$ & $\begin{array}{c}0.254 *[0.092] \\
0.363 * *[0.024] \\
0.281 *[0.076]\end{array}$ & $\begin{array}{l}116 \\
116 \\
116\end{array}$ & $\begin{array}{l}0.215 \\
0.176 \\
0.179\end{array}$ \\
\hline $\begin{array}{l}\text { Parameter } \\
\text { Averages }\end{array}$ & 0.043 & 0.352 & 0.073 & 1.093 & - & - \\
\hline
\end{tabular}

Notes: Cross-sectional logit models are estimated. For example, the estimated logit model is as follows: $y_{i, t}=\alpha+\theta_{1} T S E P_{i, t-1}+\theta_{2}(M / B)_{i, t-1}+\theta_{3}(d A / A)_{i, t-1}+\theta_{4}(E / A)_{i, t-1}+\tau_{i, t-1}$, where $y_{i, t}=1$ if the company is a payer and zero otherwise. In addition, TSEP means Tokyo Stock Exchange (TSE) First Section market capitalization percentile, that is, the percentage of firms on the TSE First Section having smaller capitalization than firm $i$ in that year, $M / B$ denotes the market-to-book ratio, $d A / A$ is the total asset growth ratio, and $E / A$ denotes the after-tax earnings-to-total-asset ratio. $* * *$ denotes the statistical significance of the coefficients at the $1 \%$ level, $* *$ denotes the statistical significance of the coefficients at the $5 \%$ level, and $*$ denotes the statistical significance of the coefficients at the $10 \%$ level, respectively. 
Table 5. Cross-Sectional Contemporaneous Determinants of Dividend Payments

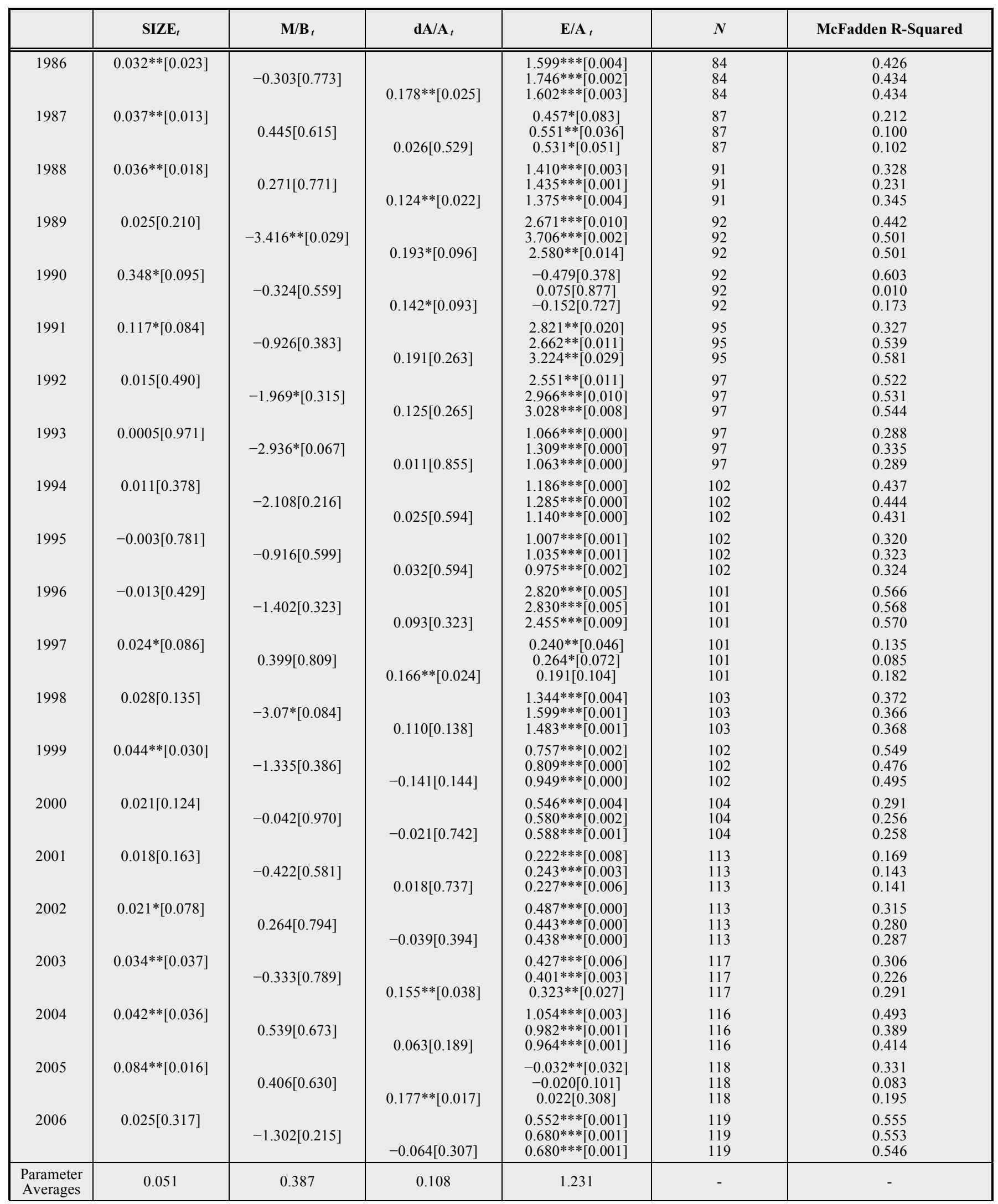

Notes: Cross-sectional logit models are estimated. For example, the estimated logit model is as follows: $y_{i, t}=\alpha+\theta_{1} T S E P_{i, t}+\theta_{2}(M / B)_{i, t}+\theta_{3}(d A / A)_{i, t}+\theta_{4}(E / A)_{i, t}+\tau_{i, t}$, where $y_{i, t}=1$ if the company is a payer and zero otherwise. In addition, TSEP means Tokyo Stock Exchange (TSE) First Section market capitalization percentile, that is, the percentage of firms on the TSE First Section having smaller capitalization than firm $i$ in that year, $M / B$ denotes the market-to-book ratio, $d A / A$ is the total asset growth ratio, and $E / A$ denotes the after-tax earnings-to-total-asset ratio. ${ }^{* * *}$ denotes the statistical significance of the coefficients at the $1 \%$ level, ${ }^{* *}$ denotes the statistical significance of the coefficients at the $5 \%$ level, and * denotes the statistical significance of the coefficients at the $10 \%$ level, respectively. 
Table 6. Cross-Sectional Determinants of One-Year-After Dividend Payments

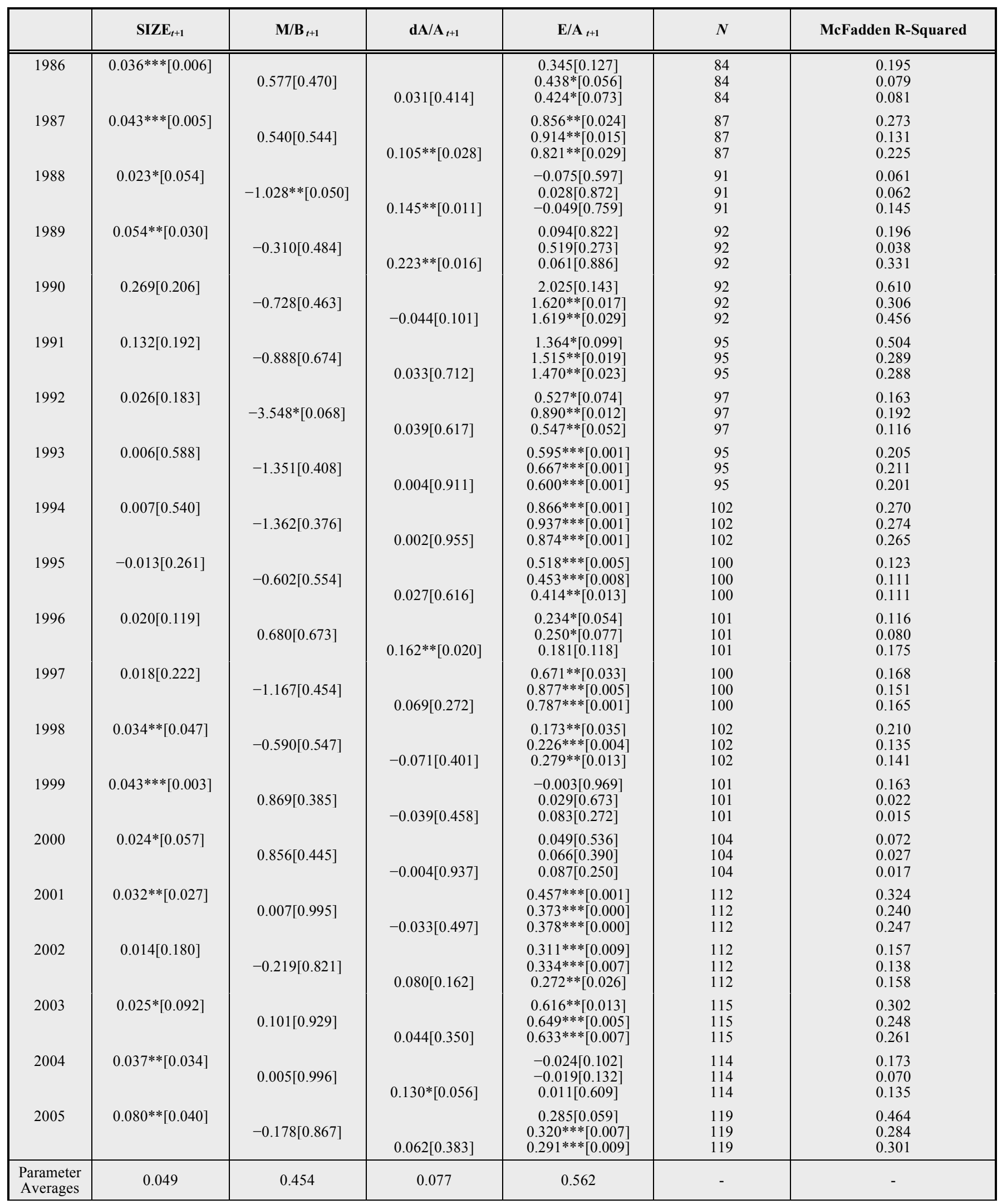

Notes: Cross-sectional logit models are estimated. For example, the estimated logit model is as follows: $y_{i, t}=\alpha+\theta_{1} T S E P_{i, t+1}+\theta_{2}(M / B)_{i, t+1}+\theta_{3}(d A / A)_{i, t+1}+\theta_{4}(E / A)_{i, t+1}+\tau_{i, t+1}$, where $y_{i, t}=1$ if the company is a payer and zero otherwise. In addition, TSEP means Tokyo Stock Exchange (TSE) First Section market capitalization percentile, that is, the percentage of firms on the TSE First Section having smaller capitalization than firm $i$ in that year, $M / B$ denotes the market-to-book ratio, $d A / A$ is the total asset growth ratio, and $E / A$ denotes the after-tax earnings-to-total-asset ratio. *** denotes the statistical significance of the coefficients at the $1 \%$ level, $* *$ denotes the statistical significance of the coefficients at the $5 \%$ level, and $*$ denotes the statistical significance of the coefficients at the $10 \%$ level, respectively. 


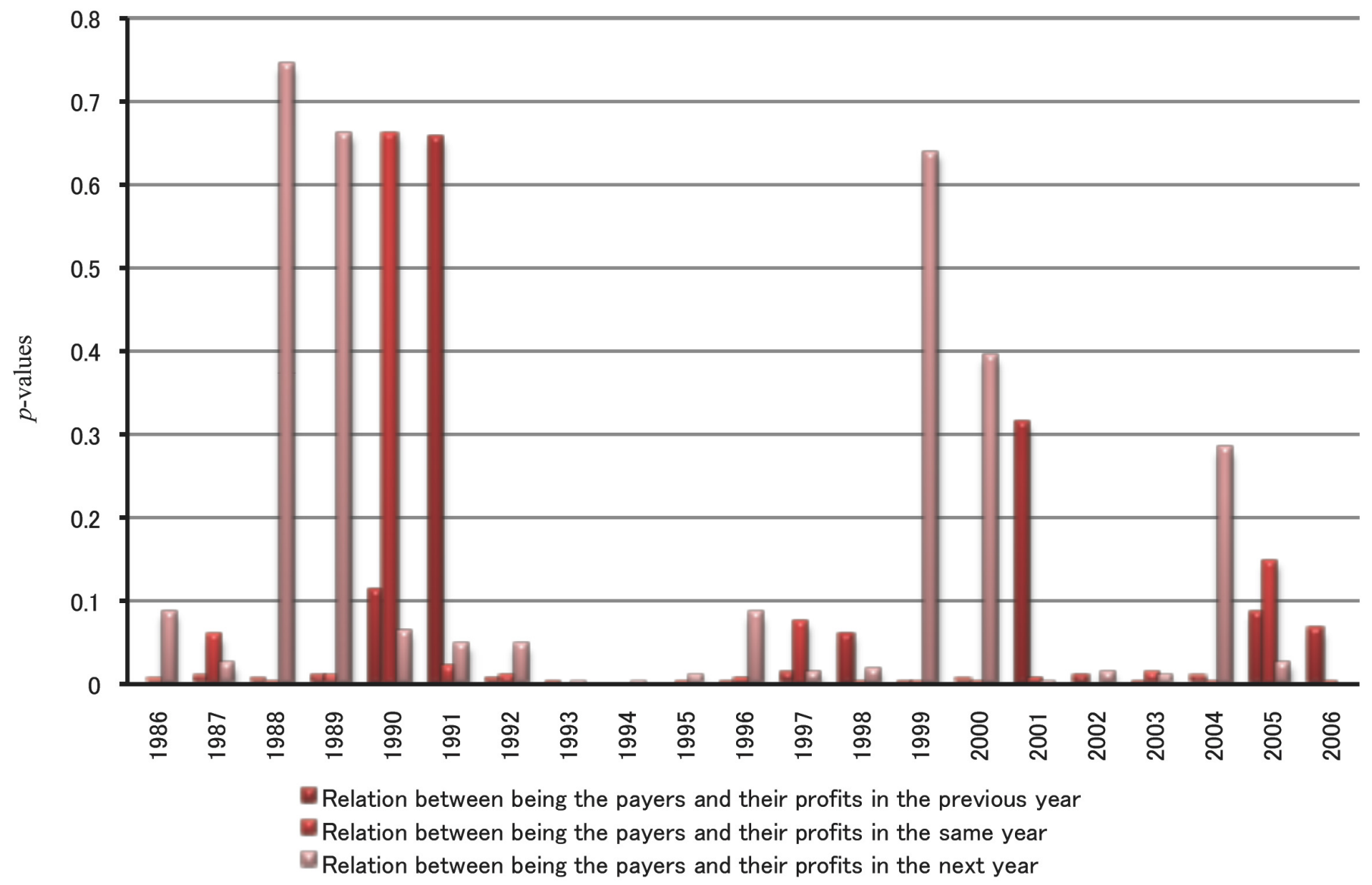

Fig. (1). Statistical Significance of the Earnings-to-Asset Ratios for the Dividend Payments. Average $p$-values of the coefficients of $E / A$ from three kinds of logit models are plotted of the period from 1986 to 2006. For instance, for deriving $p$-values regarding the contemporaneous relations between corporate dividend payments and the after-tax earnings-to-total-asset ratios, the following three models are used: (1) $y_{i, t}=\alpha+\theta_{1} T S E P_{i, t}+\theta_{2}(E / A)_{i, t}+\tau_{i, t}$, (2) $y_{i, t}=\alpha+\theta_{1}(M / B)_{i, t}+\theta_{2}(E / A)_{i, t}+\tau_{i, t}$, and (3) $y_{i, t}=\alpha+\theta_{1}(d A / A)_{i, t}+\theta_{2}(E / A)_{i, t}+\tau_{i, t}$.

\section{ADDITIONAL TIME-SERIES TESTS}

This section additionally examines the dividend policy of the Japanese chemicals industry on an aggregate time-series basis. More concretely, we perform alternative intertemporal tests by using the several kinds of multiple regressions both for Initiate and for Continue.

In the regressions, many explanatory variables considered here are as follows. First, $V W P^{D-N D}$ denotes the book value-weighted dividend premium. Second, $V W N o n p a y e r M / B \quad(V W P a y e r M / B)$ is the book valueweighted nonpayers' (payers') market-to-book ratios. Third, $V W D / P$ denotes the book value-weighted dividend yields, and fourth, VWSIZE is the book value-weighted market capitalization. Fifth, VWNonpayerSIZE (VWPayerSIZE) denotes the book value-weighted nonpayers' (payers') market capitalizations, and sixth, $V W E / A$ is the book valueweighted after-tax earnings-to-total-asset ratios. Seventh, VWNonpayerE/A (VWPayerE/A) denotes the book valueweighted nonpayers' (payers') after-tax earnings-to-totalasset ratios, eighth, Year means the time trend variable, and finally, Tax denotes the ratio of after-tax income from dividends relative to after-tax income from capital gains. Hence, the variable Tax measures the favorability of dividends in comparison with capital gains from the viewpoint of the tax systems in Japan.
Tables 7-9 indicate the results of various regressions. First, Table 7 shows the relations between dividend payments and the previous year's corporate financial conditions, Table $\mathbf{8}$ displays the contemporaneous relations between dividend payments and corporate situations, and Table 9 indicates the relations between dividend payments and the firm results in the following year.

Tables 7-9 demonstrate the results of the extensions of BW [2] and explore comprehensively the determinants of dividend payments. ${ }^{4}$ First, panel A of Table 7 indicates that dividend yields, nonpayers' $\mathrm{M} / \mathrm{B}$ and average size of all firms in the previous year are statistically significant determinants of the dividend initiations. Moreover, panel B of Table 7 demonstrates that the dividend yield and payers' $\mathrm{M} / \mathrm{B}$ in the previous year are the statistically significant determinants of dividend continuations.

Second, panel A of Table $\mathbf{8}$ indicates that only nonpayers' $\mathrm{M} / \mathrm{B}$ in the current year is a statistically significant determinant of dividend initiations. Furthermore,

\footnotetext{
${ }^{4}$ The objective of this paper is the parallel tests and the extensions of BW [2]. All regressions in Tables 7 to 9 are controlled by the variables, Tax and Year as in BW [2]. In addition, many additional new variables are tested in Tables 7 to 9. Thus these our new investigations contribute enough to our preceding key study of BW [2], and the examinations of other control variables are beyond the scope of this paper and our future work.
} 
Table 7. One-Year-Previous Time-Series Determinants of Dividend Payments

\begin{tabular}{|c|c|c|c|c|c|c|c|c|}
\hline \multicolumn{9}{|c|}{ Panel A: Initiate $_{t}$} \\
\hline $\mathrm{VW} P_{t-1}^{D-N D}$ & $\begin{array}{c}3.45 \\
{[0.47]}\end{array}$ & & & & & & & \\
\hline VW Nonpayer $M / B_{t-1}$ & & $\begin{array}{r}8.89 * * \\
{[0.02]}\end{array}$ & & & & & & $\begin{array}{c}2.58 \\
{[0.63]}\end{array}$ \\
\hline $\mathrm{VW} D / P_{t-1}$ & & & $\begin{array}{c}-10.78^{*} \\
{[0.06]}\end{array}$ & & & & & $\begin{array}{r}-7.26^{*} \\
{[0.09]}\end{array}$ \\
\hline VW SIZE $E_{t-1}$ & & & & $\begin{array}{l}9.29 * \\
{[0.07]}\end{array}$ & & & & $\begin{array}{c}4.20 \\
{[0.53]}\end{array}$ \\
\hline VW Nonpayer SIZE $E_{t-1}$ & & & & & $\begin{array}{l}-1.03 \\
{[0.78]}\end{array}$ & & & \\
\hline $\mathrm{VW} E / A_{t-1}$ & & & & & & $\begin{array}{l}-1.36 \\
{[0.66]}\end{array}$ & & \\
\hline VW Nonpayer $E / A_{t-1}$ & & & & & & & $\begin{array}{l}-0.80 \\
{[0.45]}\end{array}$ & \\
\hline $\operatorname{Tax}_{t-1}$ & 3.21 & -7.69 & -2.78 & -0.84 & -0.72 & 0.50 & -0.14 & -4.31 \\
\hline & {$[0.72]$} & {$[0.17]$} & {$[0.51]$} & {$[0.83]$} & {$[0.88]$} & {$[0.92]$} & {$[0.98]$} & [0.54] \\
\hline$Y E A R_{t-1}$ & -0.69 & 1.41 & 1.42 & -0.75 & -0.25 & -0.39 & -0.24 & 1.13 \\
\hline & {$[0.67]$} & {$[0.21]$} & {$[0.20]$} & {$[0.39]$} & {$[0.81]$} & {$[0.72]$} & {$[0.83]$} & [0.53] \\
\hline$N$ & 20 & 20 & 20 & 20 & 20 & 20 & 20 & 20 \\
\hline $\operatorname{Adj} . R^{2}$ & -0.15 & 0.00 & 0.06 & 0.03 & -0.17 & -0.17 & -0.17 & 0.01 \\
\hline \multicolumn{9}{|c|}{ Panel B: Continue $_{t}$} \\
\hline$\overline{\mathrm{VWW}} P_{t-1}{ }^{D-N D}$ & $\begin{array}{c}0.18 \\
{[0.79]}\end{array}$ & & & & & & & \\
\hline VW Payer $M / B_{t-1}$ & & $\begin{array}{l}1.59 * * \\
{[0.02]}\end{array}$ & & & & & & $\begin{array}{c}1.14^{*} \\
{[0.07]}\end{array}$ \\
\hline $\mathrm{VW} D / P_{t-1}$ & & & $\begin{array}{c}-1.59 * * \\
{[0.04]}\end{array}$ & & & & & $\begin{array}{l}-0.95 \\
{[0.20]}\end{array}$ \\
\hline VW SIZE $E_{t-1}$ & & & & $\begin{array}{c}1.00 \\
{[0.15]}\end{array}$ & & & & \\
\hline VW Payer SIZE $E_{t-1}$ & & & & & $\begin{array}{c}1.19 \\
{[0.10]}\end{array}$ & & & \\
\hline $\mathrm{VW} E / A_{t-1}$ & & & & & & $\begin{array}{c}0.04 \\
{[0.93]}\end{array}$ & & \\
\hline VW Payer E/A $A_{t-1}$ & & & & & & & $\begin{array}{c}0.40 \\
{[0.44]}\end{array}$ & \\
\hline $\operatorname{Tax}_{t-1}$ & $\begin{array}{c}0.37 \\
{[0.77]}\end{array}$ & $\begin{array}{l}-0.18 \\
{[0.79]}\end{array}$ & $\begin{array}{l}-0.16 \\
{[0.84]}\end{array}$ & $\begin{array}{c}0.14 \\
{[0.85]}\end{array}$ & $\begin{array}{c}0.27 \\
{[0.71]}\end{array}$ & $\begin{array}{c}0.16 \\
{[0.86]}\end{array}$ & $\begin{array}{l}-0.11 \\
{[0.91]}\end{array}$ & $\begin{array}{l}-0.28 \\
{[0.72]}\end{array}$ \\
\hline$Y E A R_{t-1}$ & $\begin{array}{l}-0.06 \\
{[0.76]}\end{array}$ & $\begin{array}{c}0.18 \\
{[0.29]}\end{array}$ & $\begin{array}{c}0.20 \\
{[0.31]}\end{array}$ & $\begin{array}{l}-0.10 \\
{[0.36]}\end{array}$ & $\begin{array}{l}-0.14 \\
{[0.17]}\end{array}$ & $\begin{array}{l}-0.04 \\
{[0.81]}\end{array}$ & $\begin{array}{c}0.01 \\
{[0.95]}\end{array}$ & $\begin{array}{c}0.26 \\
{[0.23]}\end{array}$ \\
\hline$N$ & 20 & 20 & 20 & 20 & 20 & 20 & 20 & 20 \\
\hline $\operatorname{Adj} \cdot R^{2}$ & -0.18 & 0.15 & 0.09 & -0.05 & 0.00 & -0.18 & -0.16 & 0.17 \\
\hline
\end{tabular}

Notes: Several regressions of dividend payment rates on measures of the dividend premium and other nominated variables are performed. For example, the initiation rate is modeled in Panel A as:

Initiate $_{t}=\alpha+\theta_{1} V W P^{D-N D}{ }_{t-1}+\theta_{2} V W N$ NonpayerM/B $B_{t-1}+\theta_{3} V W D / P_{t-1}+\theta_{4} V W S I Z E_{t-1}$

$+\theta_{5}$ VWNonpayerSIZE $_{t-1}+\theta_{6}$ VWE/A $A_{t-1}+\theta_{7}$ VWNonpayerE $/ A_{t-1}+\theta_{8}$ Tax $_{t-1}+\theta_{9}$ Year $_{t-1}+\tau_{t-1}$.

The initiation rate Initiate expresses payers as a percentage of surviving nonpayers from $t-1$.The continuation rate Continue expresses payers as a percentage of surviving payers from $t-1$. All independent variables but Year are standardized to unit variance. $p$-values are derived by the method of Newey and West [47], thus they are robust to

heteroskedasticity and serial correlation. $* *$ denotes the statistical significance of the coefficients at the $5 \%$ level, and $*$ denotes the statistical significance of the coefficients at the $10 \%$ level, respectively. $N$ is the number of sample and $A d j . R^{2}$ is the adjusted $R$-squared value.

panel B of Table 8 shows that no variable in the current year is the statistically significant determinant of dividend continuations.

Third, panel A of Table 9 shows that only nonpayers' $\mathrm{M} / \mathrm{B}$ in the following year is a statistically significant determinant of dividend initiations. We should note that this evidence that the earnings ratios in the next year are not related to dividend initiation behavior means a rejection of the signaling hypothesis in the Japanese chemicals industry. Moreover, panel B of Table 9 indicates that payers' earnings 
Table 8. Contemporanious Time-Series Determinants of Dividend Payments

\begin{tabular}{|c|c|c|c|c|c|c|c|c|}
\hline \multicolumn{9}{|c|}{${\text { Panel A: } \text { Initiate }_{t}}$} \\
\hline$\overline{\mathrm{VW}} P_{t}^{D-N D}$ & $\begin{array}{l}-2.77 \\
{[0.39]}\end{array}$ & & & & & & & \\
\hline VW Nonpayer $M / B_{t}$ & & $\begin{array}{c}11.26^{* *} \\
{[0.04]}\end{array}$ & & & & & & $\begin{array}{l}7.03 * \\
{[0.09]}\end{array}$ \\
\hline $\mathrm{VW} D / P_{t}$ & & & $\begin{array}{c}1.16 \\
{[0.83]}\end{array}$ & & & & & \\
\hline VW SIZE $E_{t}$ & & & & $\begin{array}{c}7.43 \\
{[0.21]}\end{array}$ & & & & \\
\hline VW Nonpayer $\operatorname{SIZE}_{t}$ & & & & & $\begin{array}{c}-9.83 * * * \\
{[0.00]}\end{array}$ & & & $\begin{array}{c}-7.80 * * * \\
{[0.00]}\end{array}$ \\
\hline $\mathrm{VW} E / A_{t}$ & & & & & & $\begin{array}{c}4.04 \\
{[0.32]}\end{array}$ & & \\
\hline VW Nonpayer $E / A_{t}$ & & & & & & & $\begin{array}{c}0.80 \\
{[0.42]}\end{array}$ & \\
\hline $\operatorname{Tax}_{t}$ & 6.72 & 0.48 & 9.51 & 8.60 & 5.94 & 6.06 & 9.02 & 1.14 \\
\hline & {$[0.32]$} & [0.95] & {$[0.13]$} & [0.12] & {$[0.16]$} & {$[0.43]$} & {$[0.15]$} & {$[0.83]$} \\
\hline$Y E A R_{t}$ & -0.99 & 0.76 & -1.57 & $-1.82 * *$ & $-1.58^{* *}$ & -0.99 & -1.38 & -0.21 \\
\hline & {$[0.45]$} & {$[0.62]$} & {$[0.31]$} & {$[0.02]$} & {$[0.03]$} & {$[0.45]$} & {$[0.25]$} & {$[0.84]$} \\
\hline$N$ & 20 & 20 & 20 & 20 & 20 & 20 & 20 & 20 \\
\hline $\operatorname{Adj} . R^{2}$ & 0.08 & 0.25 & -0.01 & 0.14 & 0.37 & 0.04 & -0.01 & 0.42 \\
\hline \multicolumn{9}{|c|}{ Panel B: Continue } \\
\hline$\overline{\mathrm{VWW}} P_{t}^{D-N D}$ & $\begin{array}{l}-0.48 \\
{[0.24]}\end{array}$ & & & & & & & \\
\hline VW Payer $M / B_{t}$ & & $\begin{array}{c}0.79 \\
{[0.23]}\end{array}$ & & & & & & \\
\hline $\mathrm{VW} D / P_{t}$ & & & $\begin{array}{c}0.09 \\
{[0.86]}\end{array}$ & & & & & \\
\hline VW SIZE $E_{t}$ & & & & $\begin{array}{c}0.79 \\
{[0.27]}\end{array}$ & & & & \\
\hline VW Payer $\operatorname{SIZE}_{t}$ & & & & & $\begin{array}{c}0.70 \\
{[0.32]}\end{array}$ & & & \\
\hline $\mathrm{VW} E / A_{t}$ & & & & & & $\begin{array}{c}0.98 \\
{[0.19]}\end{array}$ & & \\
\hline VW Payer E/At & & & & & & & $\begin{array}{c}0.96 \\
{[0.18]}\end{array}$ & \\
\hline $\operatorname{Tax}_{t}$ & $\begin{array}{c}0.71 \\
{[0.43]}\end{array}$ & $\begin{array}{c}0.92 \\
{[0.21]}\end{array}$ & $\begin{array}{l}1.17^{*} \\
{[0.09]}\end{array}$ & $\begin{array}{c}1.08 \\
{[0.13]}\end{array}$ & $\begin{array}{l}1.18^{*} \\
{[0.08]}\end{array}$ & $\begin{array}{c}0.37 \\
{[0.71]}\end{array}$ & $\begin{array}{c}0.29 \\
{[0.79]}\end{array}$ & \\
\hline$Y E A R_{t}$ & $\begin{array}{l}-0.09 \\
{[0.61]}\end{array}$ & $\begin{array}{l}-0.05 \\
{[0.76]}\end{array}$ & $\begin{array}{l}-0.17 \\
{[0.29]}\end{array}$ & $\begin{array}{c}-0.20 * * * \\
{[0.01]}\end{array}$ & $\begin{array}{c}-0.21 * * \\
{[0.00]}\end{array}$ & $\begin{array}{l}-0.06 \\
{[0.67]}\end{array}$ & $\begin{array}{l}-0.05 \\
{[0.74]}\end{array}$ & \\
\hline$N$ & 20 & 20 & 20 & 20 & 20 & 20 & 20 & \\
\hline $\operatorname{Adj} . R^{2}$ & -0.02 & 0.05 & -0.05 & 0.04 & 0.01 & 0.13 & 0.10 & \\
\hline
\end{tabular}

Notes: Several regressions of dividend payment rates on measures of the dividend premium and other nominated variables are performed. For example, the initiation rate is modeled in Panel A as:

Initiate $_{t}=\alpha+\theta_{1} V W P^{D-N D}{ }_{t}+\theta_{2} V W N o n p a y e r M / B_{t}+\theta_{3} V W D / P_{t}+\theta_{4} V W S I Z E_{t}$

$+\theta_{5}$ VWNonpayerSIZE $E_{t}+\theta_{6}$ VWE $/ A_{t}+\theta_{7}$ VWNonpayerE $/ A_{t}+\theta_{8}$ Tax $_{t}+\theta_{9}$ Year $_{t}+\tau_{t}$.

The initiation rate Initiate expresses payers as a percentage of surviving nonpayers from $t-1$.The continuation rate Continue expresses payers as a percentage of surviving payers from $t-1$. All independent variables but Year are standardized to unit variance. $p$-values are derived by the method of Newey and West [47], thus they are robust to heteroskedasticity and serial correlation. $* * *$ denotes the statistical significance of the coefficients at the $1 \%$ level, $* *$ denotes the statistical significance of the coefficients at the $5 \%$ level, and * denotes the statistical significance of the coefficients at the $10 \%$ level, respectively. $N$ is the number of sample and $A d j . R^{2}$ is the adjusted $R$-squared value.

and all firms' earnings in the following year are statistically significant determinants of dividend continuations.

The above results indicate that for aggregate time series, dividend premiums are not determinants of dividend payments if we take the intertemporal relations into consideration. Therefore, catering behavior among corporate managers towards investors' dividend demands is not evident in the Japanese chemicals industry. From an aggregate time-series viewpoint, in the year following dividend initiations, corporate earnings are not significant; 
Table 9. One-Year-After Time-Series Determinants of Dividend Payments

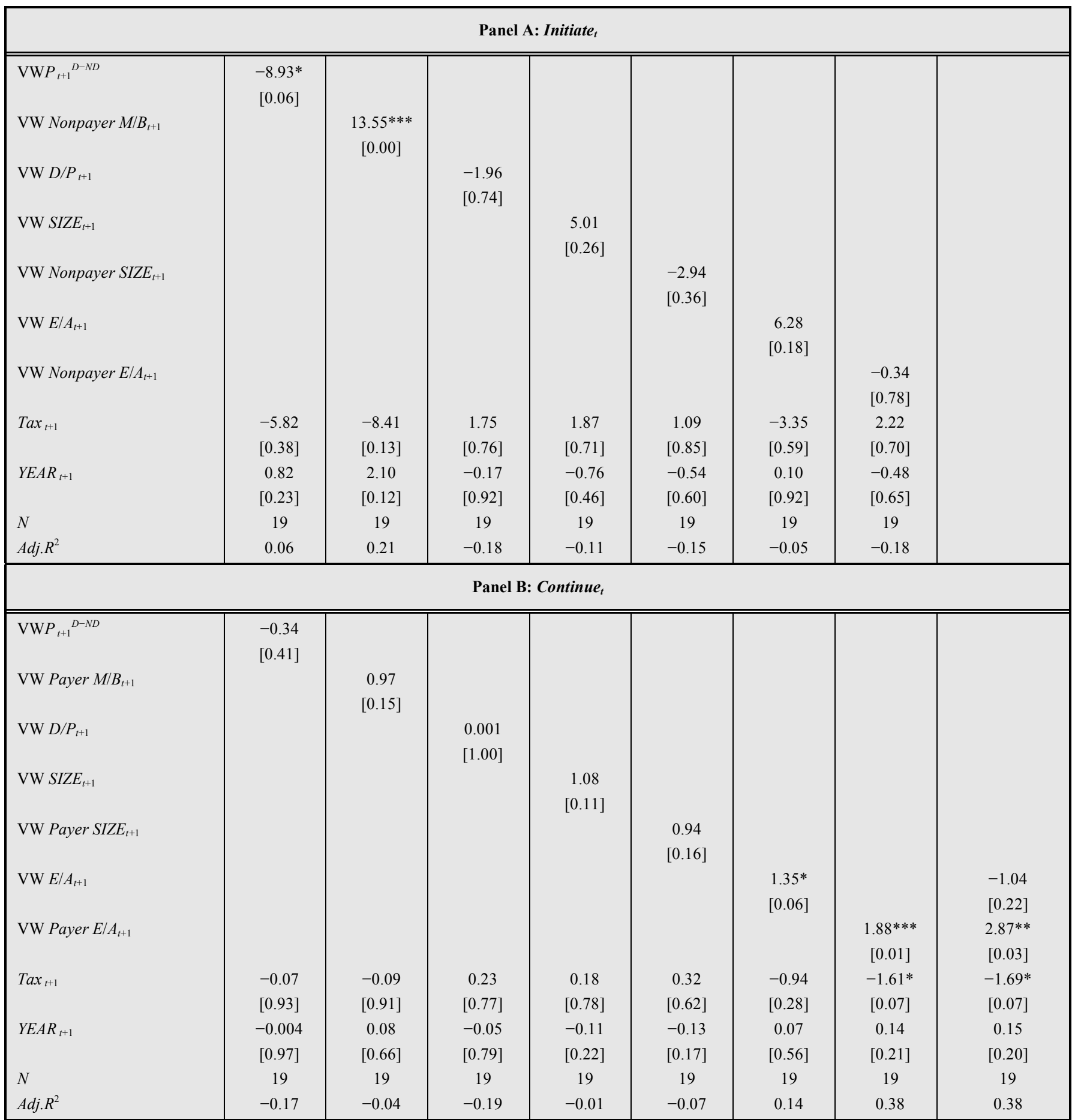

Notes: Several regressions of dividend payment rates on measures of the dividend premium and other nominated variables are performed. For example, the initiation rate is modeled in Panel A as:

Initiate $_{t}=\alpha+\theta_{1} V W P^{D-N D}{ }_{t+1}+\theta_{2} V W N o n$ payerM $/ B_{t+1}+\theta_{3} V W D / P_{t+1}+\theta_{4} V W S I Z E_{t+1}$

$+\theta_{5}$ VWNonpayerSIZE $_{t+1}+\theta_{6}$ VWE $/ A_{t+1}+\theta_{7}$ VWNonpayerE $/ A_{t+1}+\theta_{8}$ Tax $_{t+1}+\theta_{9}$ Year $_{t+1}+\tau_{t+1}$.

The initiation rate Initiate expresses payers as a percentage of surviving nonpayers from $t-1$.The continuation rate Continue expresses payers as a percentage of surviving payers from $t-1$. All independent variables but Year are standardized to unit variance. $p$-values are derived by the method of Newey and West [47], thus they are robust to heteroskedasticity and serial correlation. $* * *$ denotes the statistical significance of the coefficients at the $1 \%$ level, $* *$ denotes the statistical significance of the coefficients at the $5 \%$ level, and * denotes the statistical significance of the coefficients at the $10 \%$ level, respectively. $N$ is the number of sample and $A d j . R^{2}$ is the adjusted $R$-squared value.

thus, for the Japanese chemicals industry, the signaling hypothesis cannot be supported on an aggregate time-series basis.

\section{SUMMARY AND CONCLUSIONS}

This article investigated the determinants of dividend initiations and continuations from the perspectives of catering theory and the signaling hypothesis by focusing on 
the Japanese chemicals industry. We found the following interesting new evidence.

1. First, regarding the dividend initiations and continuations of the Japanese chemicals industry corporations, the dividend premium is not a determinant. This indicates that the Japanese chemicals industry firms do not behave as predicted by catering theory.

2. Instead, in contrast to the US case, as to dividend initiations, in the Japanese chemicals industry firms, value-weighted dividend yields, value-weighted nonpayers' $M / B$, and value-weighted size of all firms are the determinants of one-year-previous dividend initiations. These are new results obtained by extending the research of BW [2].

3. Third, from the cross-sectional viewpoint, we generally support the relationship between corporate earnings and dividend payments; however, from the aggregate time-series viewpoint, as to the Japanese chemicals industry firms, we find that corporate earnings tend to decrease in the year following dividend initiations; this means a denial of the signaling hypothesis.

As above new evidence derived in this study demonstrates, this paper contributes to the important issue of dividend policy in corporate finance. However, future related academic researches by using larger Japanese datasets will be valuable. These studies may lead to more comprehensive and stronger conclusions, and this is our future work.

\section{ACKNOWLEDGEMENTS}

I thank the Japan Society for the Promotion of Science, the Zengin Foundation for Studies on Economics and Finance, Nihon Housei Gakkai, and the Japan Securities Scholarship Foundation for their generous financial assistance for this research. I also thank two anonymous referees for their kind and constructive comments for this paper. Finally, I greatly appreciate the invitation of the Bentham Science Publishers to write for this journal as a board member of this journal.

\section{REFERENCES}

[1] Miller MH, Modigliani F. Dividend policy, growth and the valuation of shares. J Bus 1961; 34: 411-33.

[2] Baker M, Wurgler JA. Catering theory of dividends. J Financ 2004a; 59: 1125-1165.

[3] Allen F, Bernardo AE, Welch I. A theory of dividends based on tax clienteles. J Financ 2000; 55: 2499-536.

[4] Asquith P, Mullins DW. The impact of initiating dividend payments on shareholders' wealth. J Bus 1983; 56: 77-96.

[5] Bagwell LS, Shoven JB. Cash distributions to shareholders. J Econ Perspect 1989; 3: 129-140.

[6] Baker M, Wurgler JA. Appearing and disappearing dividends: the link to catering incentives. J Financ Econ 2004b; 73: 271-88.

[7] Benartzi S, Michaely R, Thaler R. Do changes in dividends signal the future or the past? J Financ 1997; 52: 1007-34.

[8] Black F. The dividend puzzle. J Portfolio Manage 1976; 2: 5-8.

[9] Black F, Scholes M. The effects of dividend yield and dividend policy on common stock prices and returns. J Financ Econ 1974; 1: $1-22$.

[10] Dann LY. Common stock repurchases: An analysis of returns to bondholders and stockholders. J Financ Econ 1981; 9: 113-138.
[11] DeAngelo H, DeAngelo L, Skinner DJ. Dividend signaling and the disappearance of sustained earnings growth. J Financ 1996; 40: 341-71.

[12] Eades KM, Hess PJ, Kim EH. Time-series variation in dividend pricing. J Financ 1994; 49: 1617-38.

[13] Fama EF, French KR. Disappearing dividends: Changing firm characteristics or lower propensity to pay? J Financ Econ 2001; 60: 3-44.

[14] Graham JR, Harvey CR. The theory and practice of corporate finance: Evidence from the field. J Financ Econ 2001; 60: 187-244.

[15] Hakansson NH. To pay or not to pay dividends. J Financ 1982; 37: 415-28.

[16] Healy PM, Palepu KG. Earnings information conveyed by dividend initiations and omissions. J Financ Econ 1988; 21: 149-76.

[17] John K, Williams J. Dividends, dilution, and taxes: A signaling equilibrium. J Financ 1985; 40: 1053-70.

[18] Kothari SP, Shanken J. Book-to-market, dividend yield, and expected market returns: A time series analysis. J Financ Econ 1997; 44: 169-203.

[19] La Porta R, Lopez-de-Silanes F, Shleifer A, Vishny R. Agency problems and dividend policies around the world. J Financ 2000; 55: 1-33.

[20] Lintner J. The distribution of incomes of corporations among dividends, retained earnings, and taxes. Am Econ Rev 1956; 46: 97-113.

[21] Long JB. The market valuation of cash dividends: A case to consider. J Financ Econ 1978; 6: 235-64.

[22] Marsh TA, Merton RC. Dividend behavior for the aggregate stock market. J Bus 1987; 60: 1-40.

[23] Michaely R, Thaler RH, Womack KL. Price reactions to dividend initiations and omissions: Overreaction or drift? J Financ 1995; 50: 573-608.

[24] Miller MH. Debt and taxes. J Financ 1977; 32: 261-75.

[25] Miller MH, Rock K. Dividend policy under asymmetric information. J Financ 1985; 40: 1031-51.

[26] Miller MH, Scholes M. Dividends and taxes. J Financ Econ 1978; 6: 333-64.

[27] Peterson P, Peterson D, Ang J. Direct evidence on the marginal rate of taxation on dividend income. J Financ Econ 1985; 14: 267-82.

[28] Poterba JM. The market valuation of cash dividends: The Citizens Utilities case reconsidered. J Financ Econ 1986; 15: 395-405.

[29] Shefrin HM, Statman M. Explaining investor preference for cash dividends. J Financ Econ 1984; 13: 253-82.

[30] Watts R. The information content of dividends. J Bus 1973; 46: 191-211.

[31] Shleifer A. Inefficient markets: An introduction to behavioral finance. Oxford University Press: Oxford, UK 2000

[32] Stein JC. Efficient capital markets, inefficient firms: A model of myopic corporate behavior. Q J Econ 1989; 104: 655-69.

[33] Stein JC. Rational capital budgeting in an irrational world. J Bus 1996; 69: 429-55.

[34] Tsuji C. What are the determinants of dividend policy? The case of the Japanese electrical appliances industry. Bus Econ J 2010: BEJ9.

[35] Korkeamaki T, Liljeblom E, Pasternack D. Tax reform and payout policy: Do shareholder clienteles or payout policy adjust? J Corp Financ 2010; 16: 572-87.

[36] Baker M. Capital Market-driven corporate finance. Anal Rev Financ Econ 2009; 1: 181-205.

[37] Baker M, Greenwood R, Wurgler J. Catering through Nominal share prices. J Financ 2009; 64: 2559-90.

[38] Chay JB, Suh J. Payout policy and cash-flow uncertainty. J Financ Econ 2009; 93: 88-107.

[39] Hoberg G, Prabhala NR. Disappegaring dividends, catering, and risk. Rev Financ Stud 2009; 22: 79-116.

[40] Denis DJ, Osobov I. Why do firms pay dividends? International evidence on the determinants of dividend policy. J Financ Econ 2008; 89: 62-82.

[41] Blau BM, Fuller KP. Flexibility and dividends. J Corp Financ 2008; 14: 133-52.

[42] Liu Y, Szewczyk SH, Zantout Z. Underreaction to dividend reductions and omissions? J Financ 2008; 63: 987-1020.

[43] Banerjee S, Gatchev VA, Spindt PA. Stock market liquidity and firm dividend policy. J Financ Quant Anal 2007; 42: 369-97. 
[44] Li W, Lie E. Dividend changes and catering incentives. J Financ Econ 2006; 80: 293-308.

[45] Fama EF, French KR. Common risk factors in the returns on stocks and bonds. J Financ Econ 1993; 33: 3-56
[46] Fama EF, French KR. Multifactor explanations of asset pricing anomalies. J Financ 1996; 51: 55-84.

[47] Newey WK, West KD. A simple, positive semi-definite, heteroskedasticity and autocorrelation consistent covariance matrix. Econometrica 1987; 55: 03-708.

(C) Chikashi Tsuji; Licensee Bentham Open.

This is an open access article licensed under the terms of the Creative Commons Attribution Non-Commercial License (http://creativecommons.org/licenses/by$\mathrm{nc} / 3.0 /$ ) which permits unrestricted, non-commercial use, distribution and reproduction in any medium, provided the work is properly cited. 